\title{
Retention of eucalyptus harvest residues reduces soil compaction caused by deep subsoiling
}

\author{
Raphael Oliveira de Melo ${ }^{1}$ Aymbiré Angeletti da Fonseca ${ }^{1}$. \\ Nairam Félix de Barros ${ }^{1} \cdot$ Raphael Bragança Alves Fernandes ${ }^{1} \cdot$ \\ Rafael da Silva Teixeira ${ }^{1} \cdot$ Iago Nery Melo $^{2} \cdot$ Ricardo Previdente Martins $^{2}$
}

Received: 24 February 2021 / Accepted: 19 April 2021 / Published online: 10 July 2021

(C) The Author(s) 2021

\begin{abstract}
Eucalyptus harvesting, forwarding and soil tillage operations are among the main causes for compaction of forest soils, with potential impacts on productivity. This concern is especially important in areas with soils that are naturally compacted (fragipans and duripans). In these soils, tillage operations include the use of subsoilers that can reach depths of more than one meter and require heavy tractors that exert high pressure on the soil. One of the ways to try to minimize the effect of this compaction is by retaining harvest residues. The objective of this study was to evaluate the impacts of eucalyptus harvesting on soil physical attributes, as well as to determine the potential of different types of residue management to reduce compaction from the soil tillage operation. Two experiments were conducted in the same area with a Yellow Argisol. In the first experiment, compaction caused by mechanized harvesting with harvester + forwarder was evaluated. In the second experiment, different managements of harvest residues were examined as potential modifiers of soil compaction during tillage for new plantings. For this, three managements systems were tested: (1) retention of all harvest residues and litter from the previous rotation $(\mathrm{HR}+\mathrm{L})$, (2) retention of litter from the
\end{abstract}

Project funding: The work is fully funded by Coordenação de Aperfeiçoamento de Pessoal de Nível Superior-Brasil (CAPES, finance code 001).

The online version is available at http://www.springerlink.com

Corresponding editor: Zhu Hong

Raphael Oliveira de Melo

raphael.o.melo@ufv.br

1 Soil Science Department, Universidade Federal de Viçosa, Viçosa, Minas Gerais, Brazil

2 BRACELL Company, Alagoinhas, Bahia, Brazil previous rotation (L), and (3) removal of harvest residues and litter from the previous rotation (WR). Before and after harvest, sampling was carried out in the planting rows and inter-rows, and after tillage, samples were collected in the traffic line of the subsoiler-tractor set. In both experiments, undisturbed soil samples were collected from the center of the $0-10,10-20,20-40,40-60$, and $60-100 \mathrm{~cm}$ layers to determine soil density and total porosity. In each period and site of evaluation, mechanical resistance to penetration up to the $60-\mathrm{cm}$ depth was also determined. The harvesting operation increased soil density at $0-10$ and $60-100 \mathrm{~cm}$ depths only in the inter-rows. Retention of harvest residues and litter $(\mathrm{HR}+\mathrm{L})$ after harvesting avoided increases in soil density and penetration resistance caused by machine traffic during tillage. The results indicate the importance of retaining harvest residues on forest soils for achieving sustainable utilization and for conserving soil quality.

Keywords Soil penetration resistance .

Harvester + forwarder $\cdot$ Soil tillage $\cdot$ Soil density $\cdot$ Cohesive soils

\section{Introduction}

Brazil has the largest area planted with eucalyptus in the world, approximately $7.5 \times 10^{6}$ ha (IBGE 2019), in addition to having one of the highest average productivities, $36 \mathrm{~m}^{3} \mathrm{ha}^{-1}$ (IBÁ 2019). An important part of the eucalyptus stands in Brazil is located in the region of the Coastal Tablelands, concentrated mainly in the states of Espírito Santo and Bahia. The soils in this region generally have naturally cohesive subsurface horizons (Moreau et al. 2006; Lima Neto et al. 2009; Gomes et al. 2012), with the presence of pans which can range from very 
hard to extremely hard when dry and from friable to firm when moist (Santos et al. 2018).

The hardened layers in the soils of the Coastal Tablelands can restrict permeability and root development, being strong limiting factor for plant production. Under these conditions, even the root system of tree species such as eucalyptus can undergo morphological and physiological changes that adversely affect growth and productivity (Bengough et al. 2011; Silva et al. 2018).

In commercial eucalyptus plantations on the coast of Bahia, subsoiling is commonly carried out to a depth of $1.1 \mathrm{~m}$ (Stape et al. 2002). This practice improves soil penetration and facilitates the growth of tree roots, which are able to explore larger volumes of soil and to absorb greater amounts of water and nutrients (Gonçalves et al. 2016). Studies have indicated the effectiveness of deep subsoiling in commercial eucalyptus plantations on cohesive soils in the region of Entre Rios, Bahia, with greater initial growth of seedlings compared to the use of holes for planting (Stape et al. 2002). Although it can be efficient as a form of soil tillage, subsoiling at great depths requires robust and heavy machines with high traction power. D8T-type tractors are often used, which exert high pressure on soils and increase compaction. Compaction reduces aeration and hydraulic conductivity and increases resistance to root system development (Tracy et al. 2011), which can limit the absorption of water and nutrients, negatively affecting productivity (Luciano et al. 2012).

At the same time, forestry activities generate large volumes of residues after harvesting operations, when up to $20 \%$ of the biomass might be left on the surface (Daystar et al. 2015). When residues are left, a protective layer is formed which reduces the contact and pressure of machines, hence lessening compaction. Maintaining the residues generated in eucalyptus harvesting minimizes the effects of soil compaction caused by machine traffic during wood forwarding (de Jesus et al. 2015; Tassinari et al. 2019). However, the compaction-reducing effect promoted by harvest residues is little known for tillage operations, especially when using robust tractors that perform subsoiling at great depths.

The hypothesis of this study is that leaving eucalyptus harvest residues on site reduces the effects of compaction caused by heavy machines used in deep subsoiling on soils with naturally cohesive horizons. This study evaluates the impact of eucalyptus harvesting on soil physical attributes and whether the retention of harvesting residues effectively lessens compaction caused during soil tillage at great depths.

\section{Material and methods}

\section{Experimental site}

The experiment was conducted in commercial eucalyptus plantations of the BRACELL company located in the municipality of Entre Rios (Bahia), at $38^{\circ} 3^{\prime} 36^{\prime \prime} \mathrm{S}$ and $12^{\circ} 1^{\prime} 17^{\prime \prime}$ W (Fig. 1). The altitude is $180 \mathrm{~m}$, with a predominant flat relief. The climate is Af, rainy tropical with dry summers (Fig. 2). The original natural vegetation was Atlantic Rainforest which has been replaced by pastures and commercial eucalyptus plantations.

The soil is sandy-loam, dystrophic cohesive Yellow Argisol according to Santos et al. (2018), which corresponds to Ultisol in the soil classes of Soil Taxonomy (Soil Survey Staff 2014). The soil belongs to the set termed 'Coastal Tablelands' of the Barreiras Group, a formation that consists of sandy-clay sediments with the sand fraction dominated almost exclusively by quartz and the clay fraction by kaolinite, in addition to low levels of iron oxides (Vilas Bôas et al. 2001).

\section{Experimental design}

A 10-ha plot (Fig. 3) of the eucalyptus clone 1404 (Eucalyptus urophylla $\times$ Eucalyptus grandis), following its third rotation, was selected and planted at $4.0 \mathrm{~m} \times 2.4 \mathrm{~m}$ spacing. The harvesting operation was of the shallow- cut type with the use of a Komatsu Harvester (HV) PC200-8 model equipped with tracks, $110 \mathrm{~kW}$ (148 HP) power and a mass of $24 \mathrm{Mg}$. Logs were forwarded with a Komatsu Forwarder (FW), 895 model, with extra-wide tires, $193 \mathrm{~kW}$ power (262 HP), mass of $18 \mathrm{Mg}$ and load capacity of $20 \mathrm{Mg}$.

After harvesting and removing the wood, the area was divided to receive three treatments related to different management of forest residues: retention of harvest residues (leaves, branches and bark) and litter from the previous rotation $(\mathrm{HR}+\mathrm{L})$; retention of only litter $(\mathrm{L})$; and, removal of all harvest residues and litter (WR). When present, the dry matter weight of the residues was equivalent to 24.0 and $10.7 \mathrm{Mg} \mathrm{ha}^{-1}$ for HR and L, respectively.

The relative proportions in the dry mass of harvest residues was $13.3 \% \pm 0.2 \%$ leaves, $22.7 \% \pm 3.7 \%$ branches, $52.6 \% \pm 3.4 \%$ bark and $11.4 \% \pm 0.3 \%$ tips (trunk segment with diameters $<4 \mathrm{~cm}$ ). In the litter, $35.4 \% \pm 5.7 \%$ and $64.6 \% \pm 6.9 \%$ corresponded to leaves and branches, respectively. The composition of the relative proportion in mass of HR was obtained after felling five trees with diameters corresponding to the mean of the stand. The means obtained were extrapolated to the number of trees present on $1 \mathrm{ha}$. Litter composition was quantified 7 days before harvest from 24 samples randomly collected using a $0.5 \mathrm{~m} \times 0.5 \mathrm{~m}$ square 


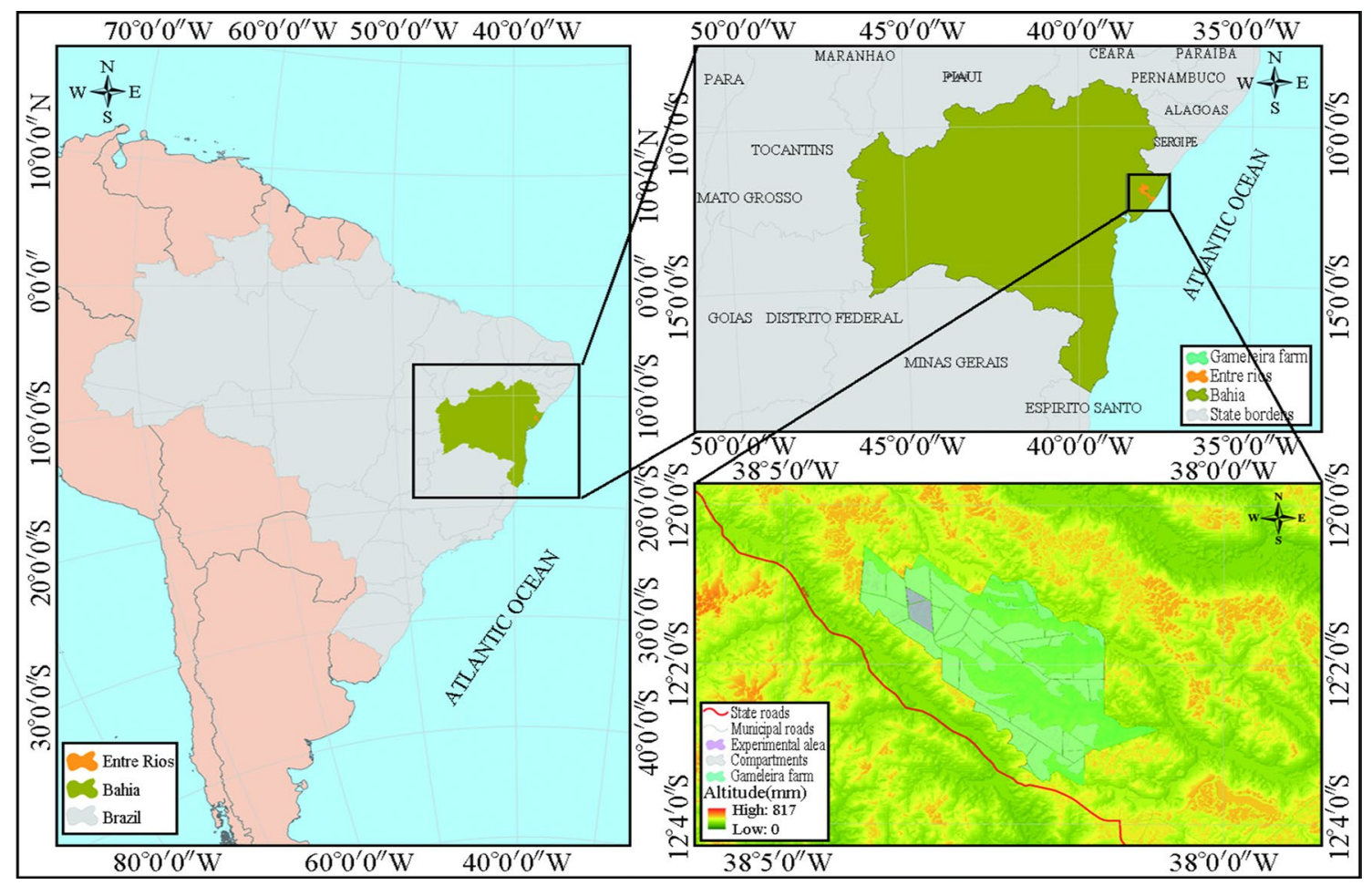

Fig. 1 Location of the experimental area in the municipality of Entre Rios-BA, Brazil ( Source: BRACELL company)

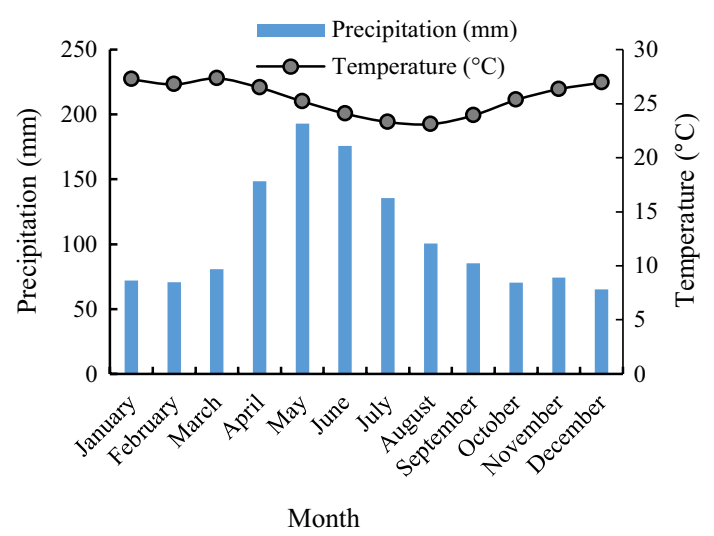

Fig. 2 Average monthly precipitation and temperature for 19882018 obtained at the Quatis weather station in the municipality of Entre Rios-BA, Brazil, located approximately $7 \mathrm{~km}$ from the experimental area ( Source: BRACELL company)

metal frame. Samples of the components of the harvest residues and litter were dried in a closed-circulation oven with air renewal at $65^{\circ} \mathrm{C}$ until reaching constant weight for moisture correction.

Tillage for the new plantation was carried out 60 days after harvest using a Caterpillar D8T tractor with tracks, $253 \mathrm{~kW}(343 \mathrm{HP})$ power and an operating mass of $38.9 \mathrm{Mg}$, using a single-shank trailed subsoiler operated to form furrows with $1.1 \mathrm{~m}$ depth and width. Subsoiling was performed in the center of the inter-row of the previous plantation.

\section{Experimental evaluations}

The study consisted up two soil compaction evaluations, the first to evaluate the result of harvesting operations and the second to evaluate the effect of the retention of harvest residues on the reduction of compaction caused by deep subsoiling.

For the evaluation of the impacts of wood harvesting and forwarding operations (traffic of $\mathrm{HV}$ and FW, respectively) on the physical quality of the soil, the area was subdivided into four blocks (Fig. 3). In each block, three random points were selected in the rows and inter-rows to collect undisturbed soil samples. Sampling was carried out before and after harvesting using cylindrical rings $5 \mathrm{~cm}$ in height and diameter in the center of the $0-10,10-20,20-40,40-60$, and $60-100 \mathrm{~cm}$ soil layers. These samples were used to determinesoil bulk density (Ds) according to Teixeira et al. (2017). To reduce spatial variability, the samplesbefore and after harvest were carried out in areas close to each other, achieved by painting the bases of tree trunks before harvest to mark the site. 


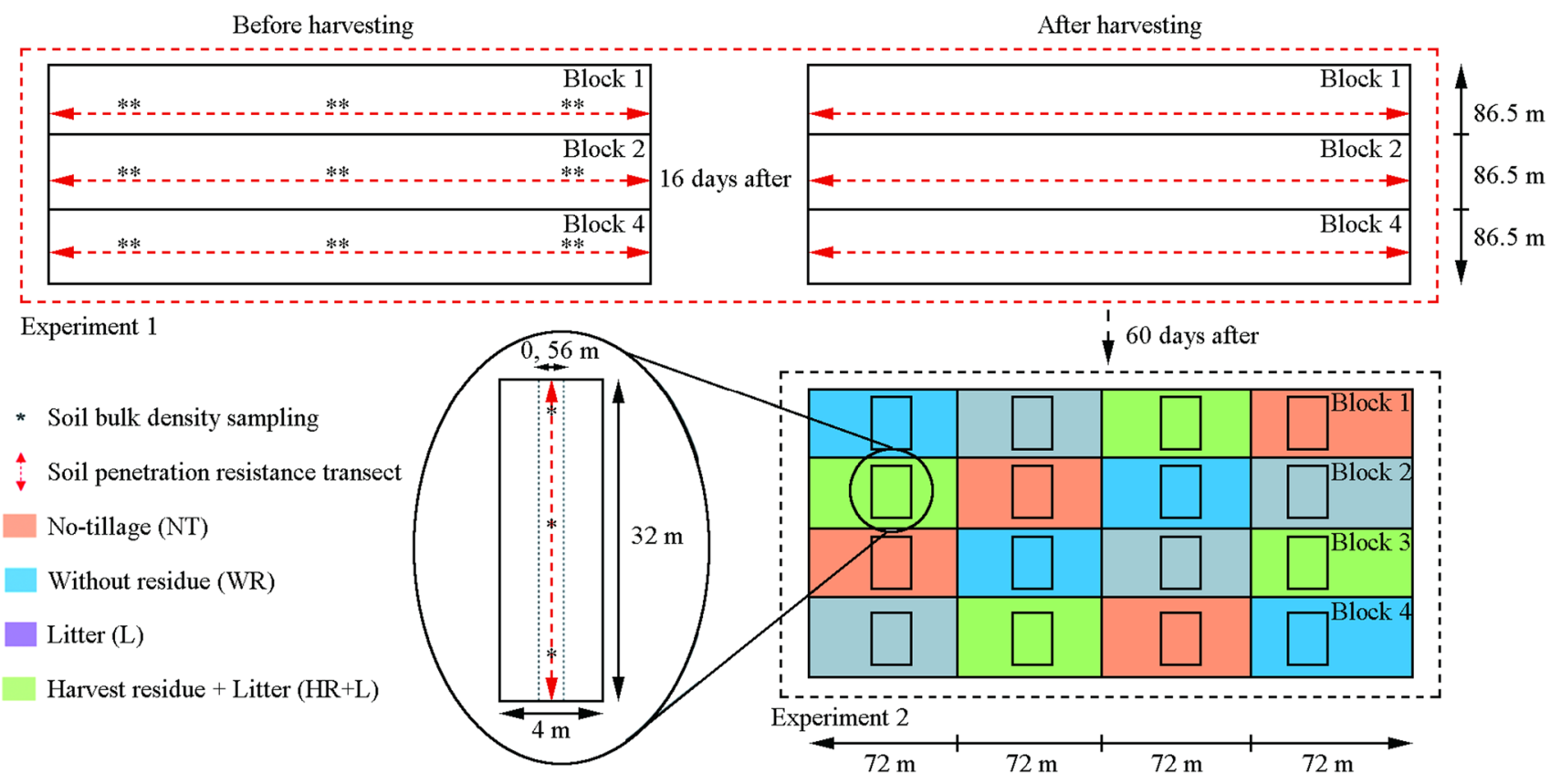

Fig. 3 Sketch of the experimental area and the experimental evaluations performed

Before and after harvesting, soil penetration resistance (PR) was evaluated up to a $60-\mathrm{cm}$ depth with a FALKER digital penetrometer, PenetroLOG-PLG 1020 model with automatic data acquisition. The penetrometer was set to record readings every $1 \mathrm{~cm}$ increment of depth, working at a constant penetration speed. PR data processing was carried out using PenetroLOG software. In each block before and after harvest, 36 observations were made in the rows and 36 in the inter-rows following a transect (Fig. 3). At the time of PR evaluations, soil samples were collected at depths of $0-10,10-20,20-40$, and $40-60 \mathrm{~cm}$ using a hand auger to determine soil moisture by the thermogravimetric method as described by Teixeira et al. (2017).

The effects of harvest residues on the mitigation of soil compaction caused by deep subsoiling were evaluated in the same experimental area (Fig. 3). An experiment was set up in a randomized complete block design with four replicates to evaluate the three types of residue management $(\mathrm{HR}+\mathrm{L}$, L and WT). Additionally, a nearby reference area which was harvested but not subject to subsoiling was also evaluated. Each replicate was formed by one $32 \mathrm{~m} \times 4 \mathrm{~m}$ area.

At the time of soil tillage and in the traffic lines of the D8T tractor (0.4-m-wide strip) pulling the subsoiler, three undisturbed samples were collected in each replicate and in the center of the 0-10, 10-20, 20-40, 40-60, and 60-100 cm soil layers to determine bulk density (Fig. 3). These same samples were used to evaluate particle density and both used to calculate total porosity (Teixeira et al. 2017). Soil penetration resistance was evaluated again up to $60 \mathrm{~cm}$ at 12 points in each replicate.
The data were subjected to the Shapiro-Wilk test to evaluate homoscedasticity and to the Hartley test to verify data normality. The data were subjected to ANOVA to test the effect of treatment on bulk density and total porosity by the Tukey test $(p<0.05)$. All statistical analyses were performed in R software version 4.0.0 (R Core Team 2018). Soil penetration resistance data were subjected to descriptive statistical analysis.

\section{Results and discussion}

\section{Effect of harvesting and forwarding on soil density and mechanical resistance to penetration}

The highest means of bulk densities were found in the upper $10 \mathrm{~cm}$ surface layer and the lowest in the deepest soil layer $(60-100 \mathrm{~cm})$ (Fig. 4). The sand content decreased with increasing depth (Table 1). Quartz present in higher percentages in the sand fraction makes the soil denser (Libardi 2005). Bulk density in the upper -10 and $60-100 \mathrm{~cm}$ layers in the inter-rows increased by $7 \%$ and $9 \%(p<0.05)$, respectively, due to wood harvesting and removal (Fig. 4).This is the predominant traffic position of the Harvester (HV) and Forwarder (FW).

The more superficial soil layers are more susceptible to compaction, as they are subject to direct pressure. In addition, they are more porous and hence more vulnerable when receiving external loads from machine traffic (Szymczak et al. 2014). However, Berisso et al. (2012) observed that 

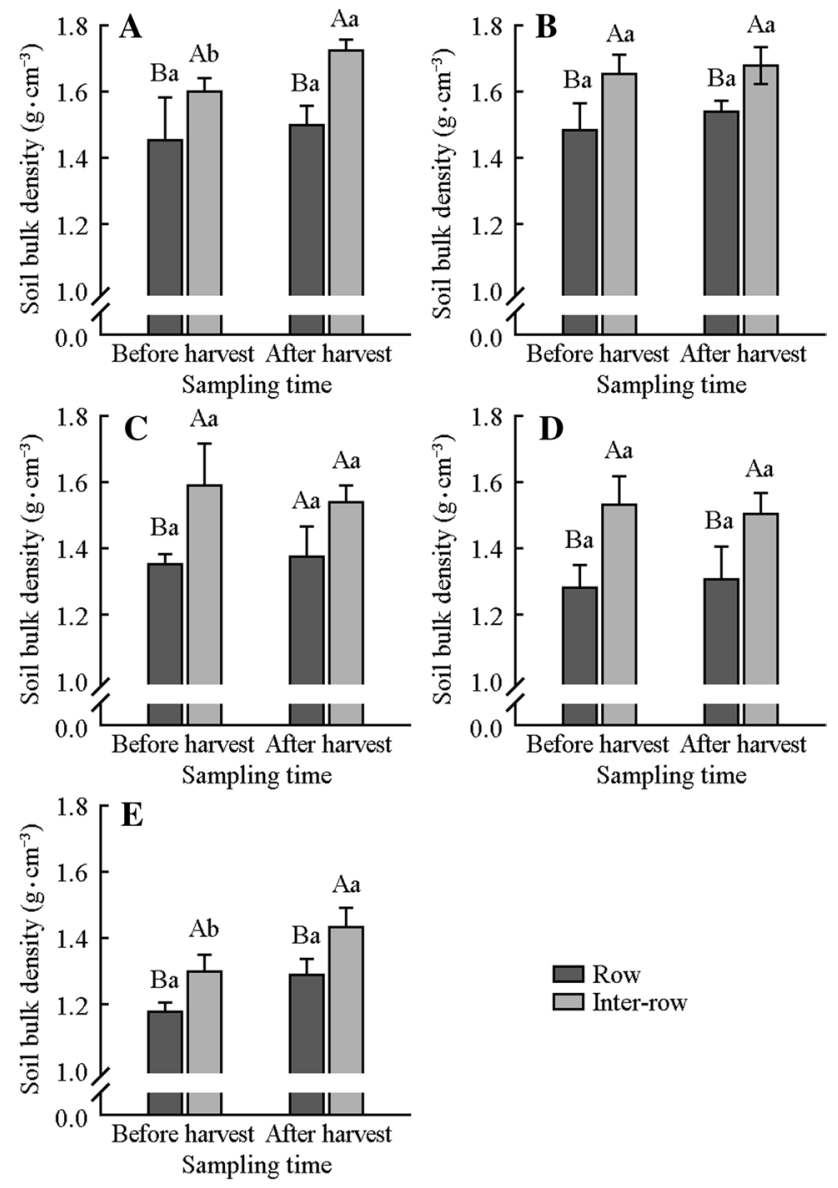

Fig. 4 Soil bulk density $\left(\mathrm{g} \mathrm{cm}^{-3}\right)$ in the planting rows and inter-rows, before and after eucalyptus harvest; A $0-10$, B 10-20, C 20-40, D 40-60, and E 60-100 cm soil layers. Equal uppercase letters did not differ from each other regarding sampling position for the same time of evaluation by Tukey test $(p<0.05)$. Equal lowercase letters did not differ regarding sampling time by Tukey test $(p<0.05)$ machine traffic can cause soil bulk density to increase up to $90 \mathrm{~cm}$ deep. The compaction process is intensified in soils with higher clay contents (Suzuki et al. 2008). As depth increased in the soil under study, there was an increase in clay content (Table 1), which led to a significant increase in bulk density in the 60-100 cm layer after $\mathrm{HV}$ and FW traffic in the inter-rows (Fig. 4).

Soil penetration resistance, unlike bulk density, was reduced after the harvest operation (Fig. 5). This was contrary to what was expected, and such divergence may be explained by differences in soil moisture at the time of each evaluation (pre- and post-harvest) (Fig. 5). The correlation between bulk density and penetration resistance depends on soil moisture at the time of penetration resistance evaluation (Dexter et al. 2007).

Soil penetration resistance evaluations at pre-harvest were performed on dry soil, with soil moisture close to the permanent wilting point (Table 1; Fig. 5). However, after harvest, soil moisture was close to field capacity (Table 1; Fig. 5). According to Assis et al. (2009), soil penetration resistance is dependent on soil moisture, and the higher the water content in the soil, the greater the changes in the conditions of friction between the perforating cone and the soil, facilitating the penetration of the rod and making the soil more plastic due to the lubricating action of the water. The cohesive Yellow Argisol soil is extremely hard when dry, and firm to friable when moist (Silveira et al. 2010; Santos et al. 2018).

Soil penetration resistance values indicate a more intense physical impediment in the inter-rows compared to the rows, regardless of the evaluation time (Fig. 4). On this site, regardless of the passage of the harvester and forwarder, in the $0-10,10-20$, and 20-40 cm layers, the average bulk density was higher than $1.5 \mathrm{~g} \mathrm{~cm}^{-3}$; this did not occur in the

Table 1 Physical and chemical characteristics of the cohesive Yellow Argisol soil in the rows and inter-rows of eucalyptus plantations at different soil layers

\begin{tabular}{|c|c|c|c|c|c|c|c|}
\hline Position & Soil layers $(\mathrm{cm})$ & $\operatorname{Sand}^{1}\left(\mathrm{~kg} \mathrm{~kg}^{-1}\right)$ & $\operatorname{Silt}^{1}\left(\mathrm{~kg} \mathrm{~kg}^{-1}\right)$ & $\operatorname{Clay}^{1}\left(\mathrm{~kg} \mathrm{~kg}^{-1}\right)$ & $\theta \mathrm{FC}^{2}\left(\mathrm{~kg} \mathrm{~kg}^{-1}\right)$ & $\theta \mathrm{PWP}^{3}\left(\mathrm{~kg} \mathrm{~kg}^{-1}\right)$ & $\operatorname{SOM}^{4}(\%)$ \\
\hline \multirow[t]{5}{*}{ Planting row } & $0-10$ & $0.75^{ \pm 0.02}$ & $0.01^{ \pm 0.01}$ & $0.24^{ \pm 0.02}$ & $0.13^{ \pm 0.01}$ & $0.07^{ \pm 0.01}$ & $2.19^{ \pm 0.40}$ \\
\hline & $10-20$ & $0.73^{ \pm 0.02}$ & $0.01^{ \pm 0.01}$ & $0.26^{ \pm 0.03}$ & $0.15^{ \pm 0.01}$ & $0.07^{ \pm 0.01}$ & $1.92^{ \pm 0.13}$ \\
\hline & $20-40$ & $0.66^{ \pm 0.04}$ & $0.01^{ \pm 0.01}$ & $0.33^{ \pm 0.04}$ & $0.18^{ \pm 0.02}$ & $0.10^{ \pm 0.01}$ & $1.55^{ \pm 0.08}$ \\
\hline & $40-60$ & $0.56^{ \pm 0.05}$ & $0.01^{ \pm 0.01}$ & $0.43^{ \pm 0.05}$ & $0.20^{ \pm 0.02}$ & $0.11^{ \pm 0.01}$ & $1.21^{ \pm 0.16}$ \\
\hline & $60-100$ & $0.49^{ \pm 0.03}$ & $0.01^{ \pm 0.01}$ & $0.50^{ \pm 0.02}$ & $0.21^{ \pm 0.03}$ & $0.13^{ \pm 0.02}$ & $0.84^{ \pm 0.17}$ \\
\hline \multirow[t]{5}{*}{ Planting inter-row } & $0-10$ & $0.76^{ \pm 0.02}$ & $0.01^{ \pm 0.01}$ & $0.23^{ \pm 0.02}$ & $0.12^{ \pm 0.01}$ & $0.06^{ \pm 0.01}$ & $2.42^{ \pm 0.01}$ \\
\hline & $10-20$ & $0.70^{ \pm 0.03}$ & $0.01^{ \pm 0.01}$ & $0.28^{ \pm 0.03}$ & $0.13^{ \pm 0.01}$ & $0.07^{ \pm 0.01}$ & $1.95^{ \pm 0.23}$ \\
\hline & $20-40$ & $0.57^{ \pm 0.02}$ & $0.01^{ \pm 0.01}$ & $0.42^{ \pm 0.03}$ & $0.15^{ \pm 0.01}$ & $0.08^{ \pm 0.01}$ & $1.31^{ \pm 0.13}$ \\
\hline & $40-60$ & $0.49^{ \pm 0.03}$ & $0.01^{ \pm 0.01}$ & $0.50^{ \pm 0.04}$ & $0.17^{ \pm 0.01}$ & $0.10^{ \pm 0.02}$ & $1.01^{ \pm 0.36}$ \\
\hline & $60-100$ & $0.46^{ \pm 0.07}$ & $0.01^{ \pm 0.01}$ & $0.53^{ \pm 0.08}$ & $0.20^{ \pm 0.03}$ & $0.12^{ \pm 0.02}$ & $1.08^{ \pm 0.36}$ \\
\hline
\end{tabular}

${ }^{1}$ Particle size analysis with the pipette method (Ruiz 2005)

${ }^{2}$ Moisture at field capacity at $-10 \mathrm{kPa}$ matrix potential

${ }^{3}$ Moisture at the permanent wilting point with matrix potential of $-1500 \mathrm{kPa}$

${ }^{4}$ Soil organic matter $=$ C.org $\times 1.724$ (Walkley Black) 
Fig. 5 Soil penetration resistance (MPa) and soil moisture $\left(\mathrm{kg} \mathrm{kg}^{-1}\right)$ in the planting rows and inter-rows, before (A) and after (B) eucalyptus harvest
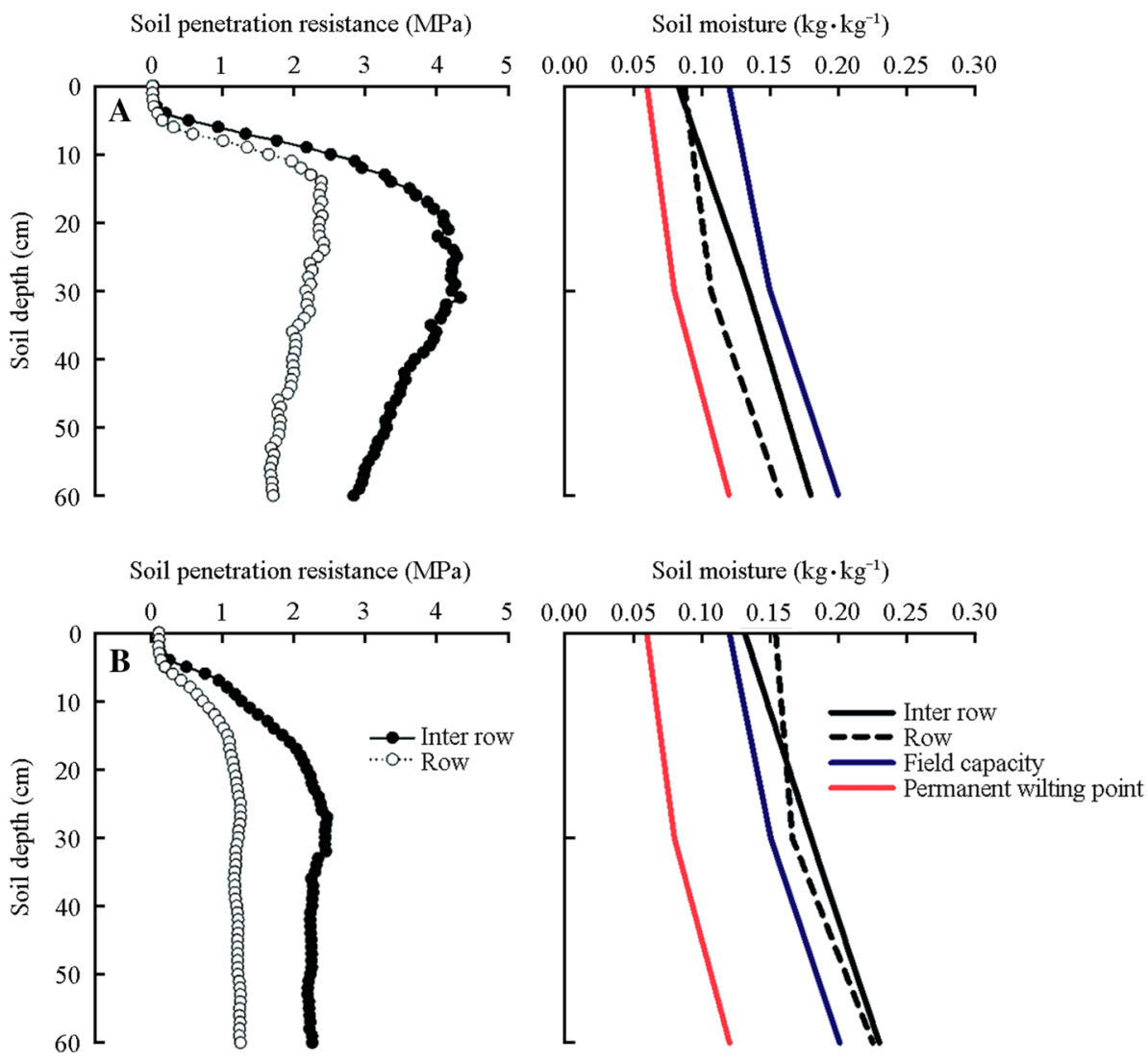

planting rows (Fig. 4). In medium-textured soil, as in the present study, Ribeiro et al. (2010) found that bulk density values $\geq 1.5 \mathrm{~g} \mathrm{~cm}^{-3}$ inhibited the development of the eucalyptus root systems. On the Coastal Tablelands of Brazil, regardless of agricultural mechanization, the average soil bulk density is $1.5-1.8 \mathrm{~g} \mathrm{~cm}^{-3}$ (Giarola and da Silva 2002). There is little information on the development of eucalyptus roots in cohesive soils. Nevertheless, root system expansion occurs mainly in rainy periods when soil moisture approaches field capacity and there is a reduction in mechanical resistance to penetration (Fig. 5). Another factor that contributes to eucalyptus root development in cohesive soils is the practice of deep subsoiling (Stape et al. 2002).

Subsoiling performed five years after soil tillage was responsible for the lower values of bulk density and soil penetration resistance in the planting rows (Figs. 4 and 5), as turning the soil causes the fracture of aggregates and development of macropores, leading to reduction of bulk density and less resistance to root penetration (Tormena et al. 2002). Additionally, there may have been more biopore formation in the planting rows due to the greater activity of edaphic fauna and tree roots, contributing to the lower bulk density and penetration resistance values (Bodner et al. 2014). The lower physical impediment in the planting rows (Figs. 4 and 5) can be critical when choosing to grow suckers instead of replanting seedlings, as soil tillage is a costly activity, especially when performed at great depths as in the Coastal Tablelands.

\section{Retention of harvest residues related to compaction}

The amount and type of harvest residues influenced the bulk density and total porosity after passing of the D8T subsoiler used for tillage. The lowest values of bulk density and the highest of total porosity were found in the upper $10 \mathrm{~cm}$ layer where the D8T impact did not occur (WT) (Fig. 6 and Table 2). The only treatment evaluated that showed results similar to those of the control area (WT) at the same depth was $\mathrm{HR}+\mathrm{L}$, in which the subsoiler passed on the harvest residues and litter from the previous rotation. At the other depths, there were no differences in bulk density and total porosity between treatments.

In the upper $10 \mathrm{~cm}$ layer, D8T traffic increased the bulk density by $9 \%, 11 \%$, and $6 \%$ and reduced porosity by $14 \%$, $16 \%$, and $10 \%$ in the $\mathrm{L}, \mathrm{WR}$ and $\mathrm{HR}+\mathrm{L}$ treatments, respectively, compared to WT. The increase in bulk density due to D8T traffic in the different treatments was not more pronounced only because of the history of pressures to which the soil was subjected, since mechanized harvesting was adopted at the beginning of the present experiment. With 


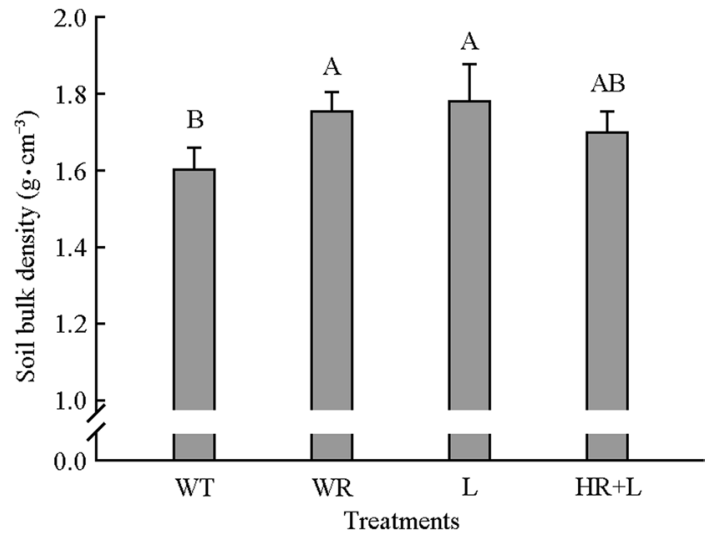

Fig. 6 Soil bulk density $\left(\mathrm{g} \mathrm{cm}^{-3}\right)$ at the $0-10 \mathrm{~cm}$ soil layer of the site where the D8T tractor passes on eucalyptus harvest residues and litter from the previous rotation $(\mathrm{HR}+\mathrm{L})$; only on the litter from the previous rotation (L); soil without residues (WR); and control, where tractor traffic did not occur (WT). Means followed by the same letter did not differ from each other by Tukey test $(p<0.05)$

Table 2 Total porosity $\left(\mathrm{m}^{3} \mathrm{~m}^{-3}\right)$ at the site where the D8T tractor passes on eucalyptus harvest residues and litter from the previous rotation $(\mathrm{HR}+\mathrm{L})$; only on litter from the previous rotation $(\mathrm{L})$; soil without residues (WR); and control, where tractor traffic did not occur (WT)

\begin{tabular}{llllll}
\hline \multirow{2}{*}{$\begin{array}{l}\text { Treat- } \\
\text { ments }\end{array}$} & \multicolumn{5}{l}{ Porosity $\left(\mathrm{m}^{3} \mathrm{~m}^{-3}\right)$ at different soil layers } \\
\cline { 2 - 6 } & $0-10 \mathrm{~cm}$ & $10-20 \mathrm{~cm}$ & $20-40 \mathrm{~cm}$ & $40-60 \mathrm{~cm}$ & $60-100 \mathrm{~cm}$ \\
\hline WT & $42.8 \mathrm{a}$ & $40.7 \mathrm{a}$ & $39.7 \mathrm{a}$ & $46.7 \mathrm{a}$ & $49.2 \mathrm{a}$ \\
WR & $37.0 \mathrm{~b}$ & $41.9 \mathrm{a}$ & $40.8 \mathrm{a}$ & $46.0 \mathrm{a}$ & $49.5 \mathrm{a}$ \\
$\mathrm{L}$ & $35.9 \mathrm{~b}$ & $41.9 \mathrm{a}$ & $41.2 \mathrm{a}$ & $47.8 \mathrm{a}$ & $45.8 \mathrm{a}$ \\
HR +L & $38.4 \mathrm{ab}$ & $39.7 \mathrm{a}$ & $40.5 \mathrm{a}$ & $51.2 \mathrm{a}$ & $51.8 \mathrm{a}$ \\
$\mathrm{CV}(\%)$ & 6.7 & 6.0 & 9.3 & 6.2 & 5.6 \\
\hline
\end{tabular}

Means followed by the same letters did not differ from each other by Tukey's test $(p<0.05)$

the harvesting and forwarding operations, bulk density in the inter-rows had increased by $7 \%$ and $9 \%$ in the $0-10$ and 60-100 cm layers, respectively, compared to the pre-harvest figure (Fig. 6). According to Williamson and Neilsen (2000), the higher the density of the soil, the less it will be prone to undergo additional compaction. Once compacted, the soil is relatively less compressible due to the higher proportion of micropores compared to macropores.

The amount and type of residues that remain on the surface mitigates the increase in bulk density and porosity resulting from machine traffic (Fig. 6; Table 2). When only litter was kept on the surface, there was no reduction of the impacts of D8T traffic, i.e., after tillage, the physical conditions of the soil were similar to areas with no residues. Bark and branches remaining on the surface in the $\mathrm{HR}+\mathrm{L}$ treatment ( $76 \%$ of the relative weight of harvest residues) are likely to be important for reducing physical damage caused by machine traffic. Silva et al. (2007), evaluating the impact of a forwarder on brushwood, brushwood + bark, soil without residues and a site without machine traffic, concluded that forest residues minimized soil compaction. They also found that soil without residues was more susceptible to compaction and that the presence of brushwood + bark promoted the greatest resistance to compaction.

Penitration resistance was also affected by D8T traffic, as can be seen from the difference between the areas under subsoiler traffic (WR, L and HR $+\mathrm{L}$ ) and the reference area WT (Fig. 7). As in the present study, Andrade et al. (2011), also found an increase in penetration resistance in the traffic lines of a subsoiler. In this study, the differences were observed in the 20-60 cm layer and resulted from the increase of clay content in the subsurface which are more compressible than sandy soils (Suzuki et al. 2008).

It was not possible to observe a well-defined penetration resistance under different types of residue management except for the 10-20 cm layer, in which areas with retention of residues ( $\mathrm{L}$ and $\mathrm{HR}+\mathrm{L}$ ) were similar to those of the reference area (WT) (Fig. 7). Plant residues reduce the contact pressure at the machine wheel-soil interface due to the increase in the contact area, reducing the applied pressure and dissipating the compaction energy on the soil (Achat et al. 2015). At the other depths, penetration resistance on
Fig. 7 Soil penetration resistance (MPa) and soil moisture $\left(\mathrm{kg} \mathrm{kg}^{-1}\right)$ at the site where the D8T tractor pass on eucalyptus harvest residues and litter from the previous rotation $(\mathrm{HR}+\mathrm{L})$; only on the litter from the previous rotation $(\mathrm{L})$; soil without residues (WR); and control, where tractor traffic did not occur (WT)
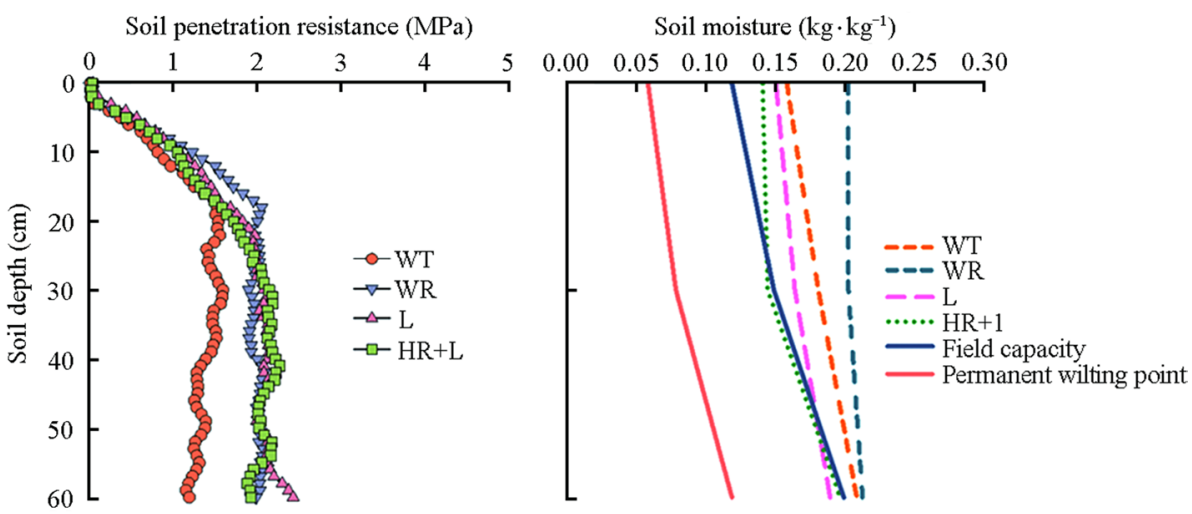
soil without residues (WR) was expected to be higher than in the other treatments with retention of residues ( $\mathrm{L}$ and $\mathrm{HR}+\mathrm{L}$ ). However, soil moisture at the time of the evaluations was higher in the treatment without residues (Fig. 7), which reduced penetration resistance at the time of evaluation (Assis et al. 2009). The lower soil moisture content in the treatments $\mathrm{L}$ and $\mathrm{HR}+\mathrm{L}$ can be attributed to the interception of rainwater by the residues (Du et al. 2019), causing a reduction in water infiltration.

Removing harvest residues is an alternative to increasing the operability of machines and implements during soil tillage, besides being an opportunity for generating extra revenue with bioenergy production, especially in the face of the growing global demand for the use of renewable sources (International Energy Agency 2019). However, the maintenance of harvest residues in the planting area increases nutrient cycling and organic matter content (Rocha et al. 2016), and contributes to mitigating soil physical deterioration under the traffic of increasingly robust machines.

\section{Conclusions}

The harvesting operation resulted in an increase in soil bulk density in the inter-rows. Retention of harvest residues reduces the impacts of machines used in soil tillage, avoiding increases in soil bulk density and root penetration resistance.

Acknowledgements Thanks are due to the BRACELL Company for financial support, providing access to the experimental area and assistence with the fieldwork. We also thank the Programa em Nutrição e Solos Florestais (NUTREE-UFV).

Open Access This article is licensed under a Creative Commons Attribution 4.0 International License, which permits use, sharing, adaptation, distribution and reproduction in any medium or format, as long as you give appropriate credit to the original author(s) and the source, provide a link to the Creative Commons licence, and indicate if changes were made. The images or other third party material in this article are included in the article's Creative Commons licence, unless indicated otherwise in a credit line to the material. If material is not included in the article's Creative Commons licence and your intended use is not permitted by statutory regulation or exceeds the permitted use, you will need to obtain permission directly from the copyright holder. To view a copy of this licence, visit http://creativecommons.org/licenses/by/4.0/.

\section{References}

Achat DL, Deleuze C, Landmann G, Pousse N, Ranger J, Augusto L (2015) Quantifying consequences of removing harvesting residues on forest soils and tree growth - a meta-analysis. For Ecol Manage 348:124-141. https://doi.org/10.1016/j.foreco.2015.03.042

Andrade GC, Bognola IA, Bellote AFJ, Franciscon L, Waterloo MJ, Bruijnzeel LA (2011) Site evaluation and productivity of a 3-year old stand of Eucalyptus urograndis in São Paulo, Brazil. Pesqui
Florest Bras 31:331-346. https://doi.org/10.4336/2011.pfb.31. 68.331

Bengough AG, McKenzie BM, Hallett PD, Valentine TA (2011) Root elongation, water stress, and mechanical impedance: a review of limiting stresses and beneficial root tip traits. J Exp Bot 62:59-68. https://doi.org/10.1093/jxb/erq350

Berisso FE, Schjønning P, Keller T, Lamandé M, Etana A, De Jonge LW, Iversen BV, Arvidsson J, Forkman J (2012) Persistent effects of subsoil compaction on pore size distribution and gas transport in a loamy soil. Soil Tillage Res 122:42-51. https://doi.org/10. 1016/j.still.2012.02.005

Bodner G, Leitner D, Kaul HP (2014) Coarse and fine root plants affect pore size distributions differently. Plant Soil 380:133-151. https:// doi.org/10.1007/s11104-014-2079-8

Daystar J, Reeb C, Gonzalez R, Venditti R, Kelley SS (2015) Environmental life cycle impacts of cellulosic ethanol in the Southern U.S. produced from loblolly pine, eucalyptus, unmanaged hardwoods, forest residues, and switchgrass using a thermochemical conversion pathway. Fuel Process Technol 138:164174. https://doi.org/10.1016/j.fuproc.2015.04.019

de Assis RL, Lazarini GD, Lanças KP, Cargnelutti Filho A (2009) Avaliação da resistência do solo à penetração em diferentes solos com a variação do teor de água. Eng Agrícola 29:558-568. https://doi.org/10.1590/s0100-69162009000400006

de Jesus GL, Silva IR, Almeida LFJ, dos Santos MA, Leite FP, Neves JCL (2015) Produtividade do eucalipto, atributos físicos do solo e frações da matéria orgânica influenciadas pela intensidade de tráfego e resíduos de colheita. Rev Bras Cienc Do Solo 39:1190-1203. https://doi.org/10.1590/01000683rbcs20140494

Dexter AR, Czyz EA, Gaţe OP (2007) A method for prediction of soil penetration resistance. Soil Tillage Res 93:412-419. https:// doi.org/10.1016/j.still.2006.05.011

Du J, Niu J, Gao Z, Chen X, Zhang L, Li X, van Doorn NS, Luo Z, Zhu Z (2019) Effects of rainfall intensity and slope on interception and precipitation partitioning by forest litter layer. CATENA 172:711-718. https://doi.org/10.1016/j.catena.2018.09. 036

Giarola NFB, Silva AP (2002) Conceitos sobre solos coesos e hardsetting. Sci Agric 59:613-620. https://doi.org/10.1590/S0103-90162 002000300030

Gomes JBV, Araújo Filho JC, de, Curi N (2012) Solos de tabuleiros costeiros sob florestas naturais e sob cultivo. Pesqui Florest Bras 32:233-246. https://doi.org/10.4336/2012.pfb.32.71.233

Gonçalves SB, da Lopes E, S Fiedler NC, Cavalieri KMV, Stahl J, Drinko CHF (2016) Efeito da profundidade de trabalho na qualidade da operação de subsolagem para implantação florestal. Rev Arvore 40:29-37. https://doi.org/10.1590/0100-6762201600 0100004

IBÁ (Industria Brasileira de Árvores), (2019) Report 2019. Indústria Brasileira de Árvores, São Paulo

IBGE (Instituto Brasileiro de Geografia e Estatística) (2019) The Brazilian Institute of Geography and Statistics. Available at: https:// sidra.ibge.gov.br/pesquisa/pevs/tabelas [acessed on 28.01.2021].

International Energy Agency (2019) World energy outlook, 2019. U.S. Department of Energy, Washington, DC, USA

Libardi PL (2005) Dinâmica da água no solo. Universidade de São Paulo, São Paulo, p 335

Lima Neto JA, Ribeiro MR, Corrêa MM, Souza Júnior VS, Lima JFWF, Ferreira RFAL (2009) Caracterização e gênese do caráter coeso em latossolos amarelos e argissolos dos tabuleiros costeiros do estado de alagoas. Rev Bras Cienc Do Solo 33:1001-1011. https://doi.org/10.1590/s0100-06832009000400024

Luciano RV, Albuquerque JA, da Costa A, Batistella B, Warmling MT (2012) Atributos físicos relacionados à compactação de solos sob vegetação nativa em região de altitude no sul do Brasil. Rev Bras 
Cienc Do Solo 36:1733-1744. https://doi.org/10.1590/S010006832012000600007

Moreau AMSS, Costa LM, Ker JC, Gomes FH (2006) Gênese de horizonte coeso, fragipã e duripã em solos do tabuleiro costeiro do sul da Bahia. Rev Bras Ciência Do Solo 30:1021-1030. https:// doi.org/10.1590/s0100-06832006000600011

R Core Team. (2018). R: A language and environment for statistical computing. R Foundation for Statistical Computing, Vienna, Austria. Available at: https://www.r-project.org [acessed on 13.02.2021].

Ribeiro MAV, Novais RF, Faquin V, Ferreira MM, Neto AEF, de Lima JM, Villani EMA (2010) Soybean and eucalyptus response to increased soil density and phosphorus doses. Rev Bras Cienc Do Solo 34:1157-1164. https://doi.org/10.1590/s0100-0683201000 0400015

Rocha JHT, Gonçalves JLM, Gava JL, Godinho TO, Melo EASC, Bazani JH, Hubner A, Arthur Junior JC, Wichert MP (2016) Forest residue maintenance increased the wood productivity of a Eucalyptus plantation over two short rotations. For Ecol Manage 379:1-10. https://doi.org/10.1016/j.foreco.2016.07.042

Ruiz HA (2005) Incremento da exatidão da análise granulométrica do solo por meio da coleta da suspensão (Silte + Argila). Rev Bras Ciência Do Solo 29:297-300. https://doi.org/10.1590/S010006832005000200015

Santos H, Jacomine P, Anjos L, Oliveira V, Lumbreras J, Coelho M, Almeida J, Araujo Filho J, Oliveira J, Cunha T (2018) Sistema Brasileiro de Classificação de Solos, 5th edn. EMBRAPA, Brasília, Brazil

Silva AR, Dias MDS, Leite FP (2007) Camada de resíduos florestais e pressão de preconsolidação de dois latossolos. Pesqui Agropecu Bras 42:89-93. https://doi.org/10.1590/S0100-204X20070001000 12

Silva SR, Barros NF, Novais RF, Comerford NB (2018) Eucalyptus growth and phosphorus nutritional efficiency as affected by soil compaction and phosphorus fertilization. Commun Soil Sci Plant Anal 49:2700-2714. https://doi.org/10.1080/00103624.2018. 1538372

Silveira DC, Melo Filho JF, Sacramento JAAS, Silveira ECP (2010) Relação umidade versus resistência à penetração para um argissolo amarelo distrocoeso no recôncavo da Bahia. Rev Bras Ciência Do Solo 34:659-667. https://doi.org/10.1590/S0100-0683201000 0300007

Soil Survey Staff (2014) Keys to Soil Taxonomy, 12th edn. United States Department of Agriculture, Washington, DC, USA

Stape JL, Andrade SC, Gomes AN, Krejci LC, Ribeiro JACL (2002) Definições de métodos de preparo de solo para silvicultura em solos coesos do litoral norte da Bahia. In: Gonçalves JLM, Stape JL (eds) Conservação e cultivo de solos para plantações florestais. Piracicaba, Brazil, IPEF

Suzuki LEAS, Reinert DJ, Reichert JM, Lima CLR (2008) Estimativa da susceptibilidade à compactação e do suporte de carga do solo com base em propriedades físicas de solos do Rio Grande do Sul. Rev Bras Ciência Do Solo 32:963-973. https://doi.org/10.1590/ s0100-06832008000300006

Szymczak DA, Brun EJ, Reinert DJ, Frigotto T, Mazzalira CC, Dal'ColLúcioMarafiga AJ (2014) Compactação do solo causada por tratores florestais na colheita de Pinus taeda L. na região sudoeste do Paraná. Rev Arvore 38:641-648. https://doi.org/10. 1590/S0100-67622014000400007

Tassinari D, Andrade MLC, Dias Junior MS, Martins RP, Rocha WW, Pais PSAM, de Souza ZR (2019) Soil compaction caused by harvesting, skidding and wood processing in eucalyptus forests on coarse-textured tropical soils. Soil Use Manag 35:400-411. https://doi.org/10.1111/sum.12509

Teixeira PC, Donagemma GK, Fontana A, Teixeira WG (2017) Manual de métodos de análise de solo, 3rd edn. EMBRAPA, Rio de Janeiro, Brazil

Tormena CA, Barbosa MC, da Costa ACS, Gonçalves ACA (2002) Densidade, porosidade e resistência à penetraç ão em latossolo cultivado sob diferentes sistemas de preparo do solo. Sci Agric 59:795-801. https://doi.org/10.1590/S0103-90162002000400026

Tracy SR, Black CR, Roberts JA, Mooney SJ (2011) Soil compaction: a review of past and present techniques for investigating effects on root growth. J Sci Food Agric 91:1528-1537. https://doi.org/ $10.1002 /$ jsfa. 4424

Vilas Bôas GS, Sampaio FJ, Pereira AMS (2001) The barreiras group in the northeastern coast of the State of Bahia, Brazil: depositional mechanisms and processes. An Acad Bras Cienc 73:416-427. https://doi.org/10.1590/s0001-37652001000300010

Williamson JR, Neilsen WA (2000) The influence of forest site on rate and extent of soil compaction and profile disturbance of skid trails during ground-based harvesting. Can J for Res 30:1196-1205. https://doi.org/10.1139/x00-041

Publisher's Note Springer Nature remains neutral with regard to jurisdictional claims in published maps and institutional affiliations. 